\title{
On the footsteps of Théodore Monod: biogeographical and ecological implications of an insect assemblage from the hottest spot on earth (in central Lut Desert, SE Iran)
}

\author{
Philippe Ponel ${ }^{*}$, Morteza Djamali ${ }^{1,2}$, Patrice Bordat ${ }^{3}$, Manfred Jäch ${ }^{4}$, Denis Keith ${ }^{5}$, Hamid Lahijani², Philippe \\ Magnien ${ }^{6}$,Armand Matocq ${ }^{6}$, Abdolmajid Naderi Beni $^{2}$, Giuseppe Platia ${ }^{7}$ \& Hamed Pourkhorsandi ${ }^{8}$ \\ ${ }^{1}$ Institut Méditerranéen de Biodiversité et d'Ecologie (IMBE), Aix Marseille Univ, Univ Avignon, CNRS, IRD, Technopôle \\ Arbois-Méditerranée, Bât. Villemin, BP 80, F-13545 Aix en-Provence cedex 04, France \\ ${ }^{2}$ Iranian National Center for Oceanography and Atmospheric Sciences (INIOAS), No.9 Etemad Zadeh St., West Fatemi \\ Ave, 14155-4781 Tehran, Iran \\ ${ }^{3} 495$ route de Caussade, F-82300 Saint-Cirq, France \\ ${ }^{4}$ Naturhistorisches Museum Wien, 1010 Wien, Austria \\ ${ }^{5} 120$ rue Gabriel Péri, F-28000 Chartres, France \\ ${ }^{6}$ Muséum national d'Histoire Naturelle, Département Adaptations du Vivant, UMR 7179, MECADEV, MNHN/CNRS, En- \\ tomologie, CP50, 57 rue Cuvier, F-75231 Paris cedex 05, France \\ ${ }^{7}$ Via Molino Vecchio 21/a, I-47043 Gatteo (FC), Italy \\ ${ }^{8}$ Laboratoire G-Time, Université Libre de Bruxelles, CP 160/02, 50 av. F.D. Roosevelt, B-1050 Brussels, Belgium \\ *Corresponding author, email: philippe.ponel@imbe.fr
}

\begin{abstract}
We present the entomological results of a geological and biological exploration in the Lut desert, performed in 2014 by the Iranian National Institute for Oceanography and Atmospheric Sciences (INIOAS) and the University of Tehran. Five localities were sampled, including the one considered as the the hottest spot on Earth. They yielded 15 insect taxa belonging to Blattodea, Orthoptera, Coleoptera, Heteroptera, suggesting that in spite of being originally described as "abiotic" or "aphytic", the Lut desert shelters a diverse insect fauna with some remarkable elements such as the endemic desert cockroache Leiopteroblatta monodi. Comparison with results obtained by Franco-Iranian expeditions in the sixties and seventies reveals several taxa in common, but also striking differences in the composition of the insect assemblages, suggesting that the insect fauna in the Lut desert is potentially much more diverse than previously expected.
\end{abstract}

KEY WORDS Lut insect fauna; aphytic; abiotic; Irano-Turanian; Saharo-Sindian.

Received 02.03.2020; accepted 13.05.2020; published online 30.09.2020

\section{INTRODUCTION}

The Lut Desert (also "Lout" and "Loute") in Southeast Iran is one of the most hostile places on Planet Earth. It has been registered as World Heritage site in 2016 meeting criteria VII and VIII displaying exceptional natural beauty and unique geological and biological features (https://whc.un- esco.org/en/list/1505/). Its southern extremity has been suggested as the hottest spot on Earth (Mildrexler et al., 2006, 2011; Stone, 2016; Azarderakhsh et al., 2020).

Théodore Monod in his famous book "Les Déserts" (1973) states that he has measured sand temperatures of up to $55^{\circ} \mathrm{C}$ in February and suggests the possibility of summer temperatures rising 
up to about $80^{\circ} \mathrm{C}$ ! Such extremely high temperatures have recently been confirmed by instrumental measurements which reveal $61{ }^{\circ} \mathrm{C}$ temperature in July 2014 (Pourkhorsandi et al., 2019). Most of the Lut Desert has been described as "abiotic" or at least "aphytic" due to the near absence of any visible sort of life (Dresch, 1968; Monod, 1973; Mobayen, 1976).

Even if the "azoïc" or "abiotic" nature of the central Lut (Dresch, 1968; Monod, 1973) has recently been questioned by several adventurers who have observed some animal life, the almost aphytic nature (Mobayen, 1976) of this area especially in Kalut and Central Hammada is almost evident.

Austrian adventurers and geographers A. Gabriel and G. Stratil-Sauer are the first western scientists who have traversed the Lut Desert and have given detailed account on their physical and biological observations of the desert (Gabriel, 1938; Stratil-Sauer, 1956). However, the first systematic study on the geomorphology and ecology of Lut was performed in the framework of several FrancoIranian joint missions in the late 1960's and early 1970 's and resulted in a number of short papers and reports (e.g., Dresch, 1968; Pierre, 1969, 1970, 1974). In 2014, two scientific expeditions with geological and geomorphological objectives were organized by Iranian National Institute for Oceanography and Atmospheric Sciences (INIOAS) and the University of Tehran (March and April 2014). Although the central parts of the desert were found almost totally "aphytic", the visitors (M. Djamali, H. Pourkhorsandi) encountered a remarkable diversity of insects especially during the second field excursion (16-20 April 2014) and took this opportunity to sample this fauna.

This study reports the identified arthropod samples collected during these expeditions. It also provides a short description on the ecological context in which these insect assemblages were collected and the biogeographical implications inferred from their presence.

\section{PHYSICAL AND BIOGEOGRAPHICAL SETTING}

\section{Geomorphology}

Lut (Dasht-e Lut) is an approximately 80,000 $\mathrm{km}^{2}$ desertic territory located in southeastern Iran (Fig. 1). Geologically, it forms a rigid block called 'Lut Block' separated from its adjacent tectono-sedimentary units by complex fault systems especially in the East and West (Stocklin, 1968). Geomorphologically, it contains a variety of landforms of very different dimensions that can be simplified as the following units:

(i) Kalut. Kalut represent a complex system of NWN-SES directed parallel valleys and crests formed due to strong aeolian erosion over a long but unknown geological time. Their formation is mostly due to wind erosion, the wind abrasion being 3 to 4 times stronger in the valleys (grooves) than over the crests (Ghodsi, 2017). They cover an area of $\sim 70 \mathrm{x}$ $\sim 120 \mathrm{~km}$ in western Lut (Fig. 1). Kalut are sometimes referred to as "yardangs" (e.g., Ghodsi, 2017).

If the use of this term is accepted, they represent most probably the highest yardangs on Earth (Dresch, 1968). Kalut seem to be of the same geological composition as Central Hammada (see below) but having undergone a deep fluvio-aeolian erosion during the Neogene.

(ii) Central Hammada. This geomorphological unit essentially occupies the central and northwestern part of Lut (Fig. 1). Although Kalut also seem to be almost deprived of animal and plant life unless in their marginal zone, the specific "abiotic" zone of Lut is often used to describe this part of the desert (Mobayen, 1976). Central Hammada are not totally flat but show a complex drainage pattern, terraced surfaces; small and large polygonal structures formed due to the growth of evaporates in soil and many other geomorphological features.

Strong deflation seems to have contributed in the formation of several endorheic depressions such as "Hamoun-e Shūrgaz" (Fig. 1).

(iii) Rig-e Yalan Erg. This is a huge erg (sand sea) covering an area of $\sim 65 \times 130 \mathrm{~km}$ located in eastern Lut. Due to exceptionally high elevations of huge sand dunes of this desert (up to $>400 \mathrm{~m} \mathrm{ac}$ cording to unpublished sources) especially in its central parts, some scholars have referred them as "dune massifs" (Mobayen, 1976). Barkhans and star dunes occupy smaller territories compared to Rig-e Yalan and are especially found bordering the latter.

\section{Bioclimatology}

Iran displays a wide variety of bioclimates rang- 
ing from "temperate oceanic" bioclimate in south Caspian region, "Mediterranean" bioclimates over the central Iranian plateaus and mountain ranges and "tropical arid/hyperarid" bioclimates in the south and southeast (Djamali et al., 2011). In this broad spectrum of bioclimates, the driest and hottest bioclimate, i.e., the "tropical hyperarid" is found in the Lut Desert (Fig. 2). It is characterized by a long dry season $(\mathrm{P}<2 \mathrm{~T})$ lasting all the year. Only one meteorological station was found to be close

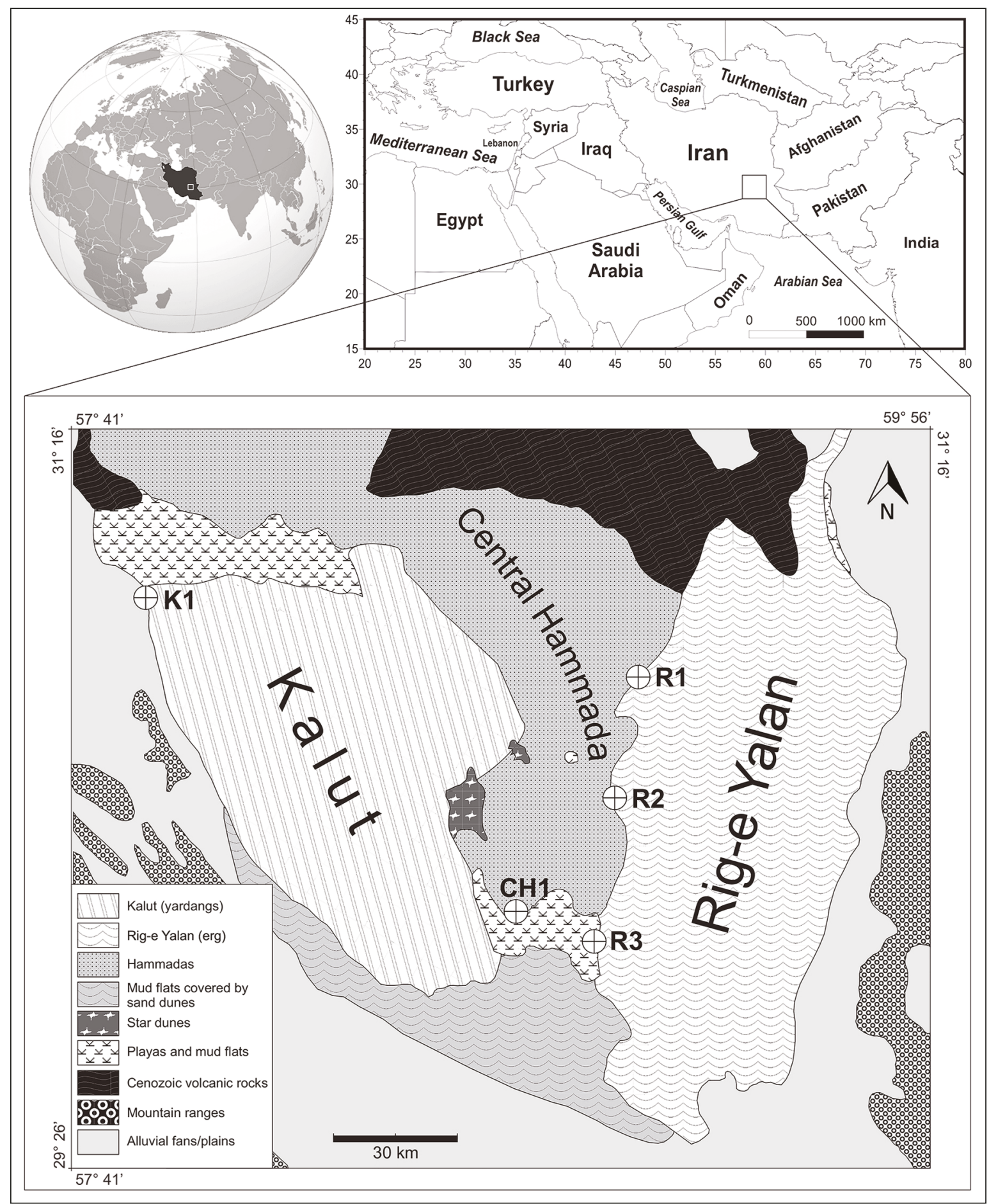

Figure 1. Lut desert and location of the sampling sites. 
enough to central Lut to give a general estimation of the harsh climatic conditions of Lut (see climate diagram in figure 2). Over a 13-year long meteorological record (1986-2003), the average of maxima of the hottest month have been measured as $47.5^{\circ} \mathrm{C}$ while the hottest absolute temperature ever measured has been about $55^{\circ} \mathrm{C}$ (July 1995). The mean annual precipitation has been as low as $28 \mathrm{~mm}$. One could easily imagine a still higher temperatures and lower precipitations in central Lut Desert especially

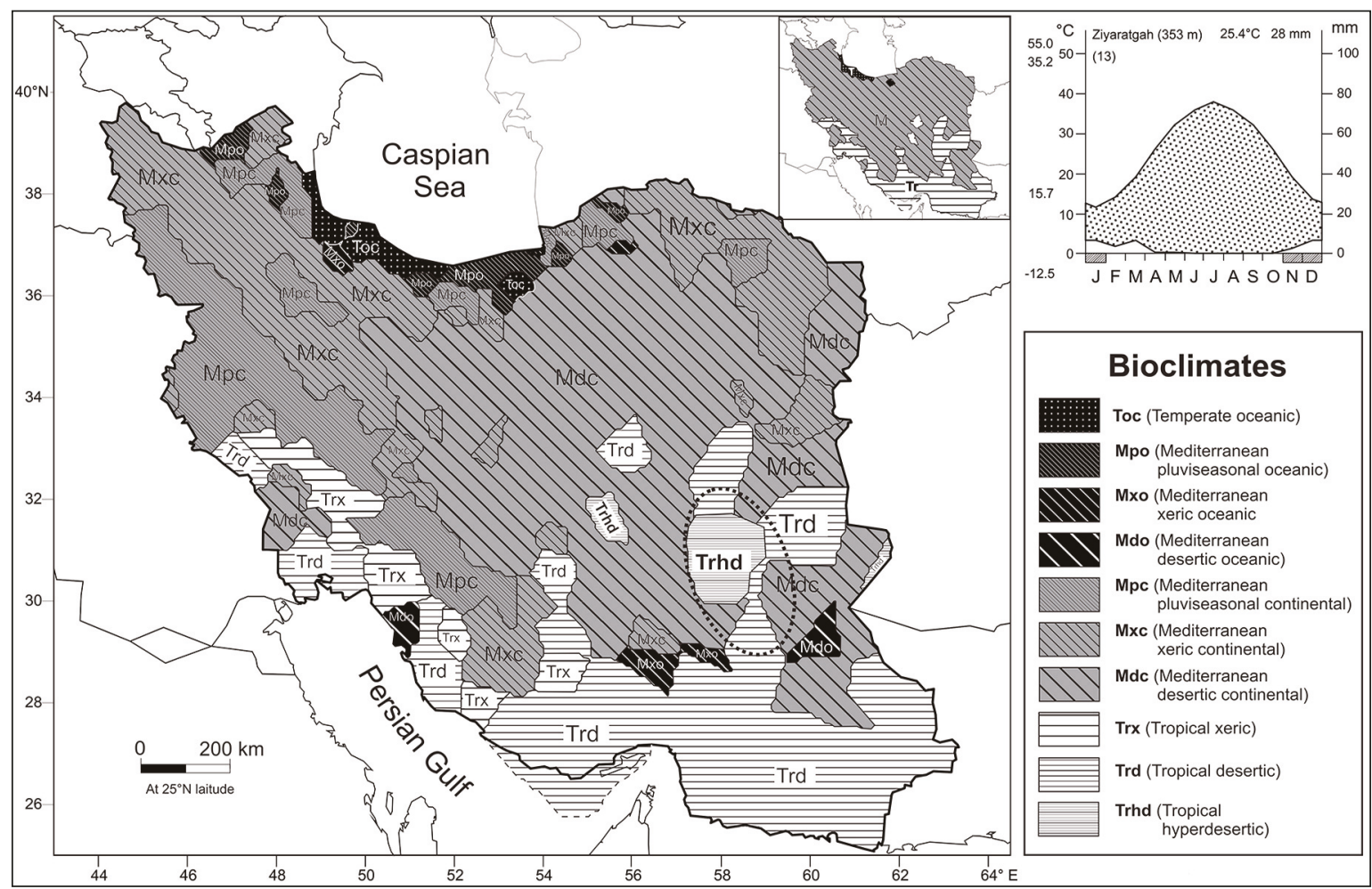

Figure 2. Bioclimates of Iran, Lut desert in the dotted circle.

\begin{tabular}{|c|c|c|c|c|c|c|}
\hline Site & Lat. (N) & $\begin{array}{l}\text { Coordinates } \\
\text { Long. (E) }\end{array}$ & Alt. (m) & Date & $\begin{array}{l}\text { Time } \\
\text { (Hour) }\end{array}$ & Description \\
\hline K1 & $30^{\circ} 47^{\prime} 19.35^{\prime \prime}$ & $57^{\circ} 47^{\prime} 6.04^{\prime \prime}$ & 306 & $30 / 03 / 2014$ & 22 & $\begin{array}{l}\text { Kalut: NWN-SES directed valley floor bordered } \\
\text { by } 40 \mathrm{~m} \text { high hills. Valley floor is covered by } \\
\text { coarse aeolian sands. }\end{array}$ \\
\hline R1 & $30^{\circ} 36^{\prime} 6.09^{\prime \prime}$ & $59^{\circ} 11^{\prime} 37.48^{\prime \prime}$ & 596 & $29 / 03 / 2014$ & 09 & $\begin{array}{l}\text { Rig-e Yalan: Sand dunes in NW of Rig-e Yalan at } \\
\text { the very proximity of Central Hamadas }\end{array}$ \\
\hline $\mathrm{R} 2$ & $30^{\circ} 18^{\prime} 19.26^{\prime \prime}$ & $59^{\circ} 7^{\prime} 48.51^{\prime \prime}$ & 511 & $20 / 04 / 2014$ & 21 & $\begin{array}{l}\text { Rig-e Yalan/Central Hamadas transition: A hamada } \\
\text { bordered and partly covered by sand dunes. }\end{array}$ \\
\hline R3 & $29^{\circ} 57^{\prime} 26.79^{\prime \prime}$ & $59^{\circ} 4^{\prime} 15.45^{\prime \prime}$ & 292 & $19 / 04 / 2014$ & 21 & $\begin{array}{l}\text { Rig-e Yalan: Sand dunes in SE of Rig-e Yalan at the } \\
\text { proximity of Central Hamadas; supposedly the } \\
\text { hottest spot on Earth (Midrexler et al., 2009). }\end{array}$ \\
\hline $\mathrm{CH} 1$ & $30^{\circ} 4^{\prime} 22.63^{\prime \prime}$ & $58^{\circ} 55^{\prime} 22.65^{\prime \prime}$ & 285 & $18 / 04 / 2014$ & 21 & $\begin{array}{l}\text { Central Hamadas: Isolated outcrops of Kalouts in } \\
\text { the Central Hamadas. Beetles were collected } \\
\text { inside and besides salty spring bordered with a } \\
\text { band of a monospecific Tamarix stand. }\end{array}$ \\
\hline
\end{tabular}

Table 1. Sampling sites. 
in the supposedly "hottest spot on Earth" (Mildrexler et al., 2006, 2011). A Thermometer installed in near standard conditions of meteorological stations in 2014 , recorded $61{ }^{\circ} \mathrm{C}$ in July 2014 suggesting that the soil temperatures exceeding $70{ }^{\circ} \mathrm{C}$ are quite possible (Pourkhorsandi et al., 2019).

\section{Biogeography}

The delineation of the phytogeographical limits of the Saharo-Sindian and Irano-Turanian regions at Lut Desert is not still well defined (Djamali et al., 2011, 2012). Léonard (1981-1989, 1991/1992) describes the Lut Desert as belonging to the IranoTuranian floristic region. However, unlike the more north-central Iranian deserts, less than half of the species found in the periphery of this desert belong to the Irano-Turanian endemic species and there is a considerable percentage of plants belonging to other regions. This makes Léonard to define the Lut as a "Local zone of endemic impoverishment" within the "Irano-Turanian regional zone of endemism" (Léonard, 1993). Indeed, 35.6\% of the Lut elements belong to the Irano Turanian region while $16.8 \%$ to the Saharo-Sindian region, $7.6 \%$ to Nubo-Sindian, $4.2 \%$ to Somalia-Massai, $0.7 \%$ to Indian regions and the rest of the elements are the linking species simultaneously found in several regions. The psamophilous beetle fauna of Lut also shows many similarities with north-western Saharan elements at the genus level confirming the strong zoogeographical imprint of Saharo-Sindian fauna on the Lut fauna (Pierre, 1974).

\section{MATERIAL AND METHODS}

During our two expeditions to central Lut, we did not observe any sign of plant life in Kalut and Central Hammada with the exception of a very small stand of Tamarix in CH1 site (see below) and presence of very sparse psammophytes ( $\mathrm{Cal}$ ligonum spp. and Cyperus spp. and Brassicaceae) in the interior parts of Rig-e Yalan. However, we were surprised by the high abundance of insect fauna. The predominant insect groups encountered were beetles, bugs, grasshoppers, moths, and a species of wind spider (not treated in this study). Blattodea, Orthoptera, Coleoptera Carabidae and Coccinellidae were studied by P. Ponel;
Coleoptera Hydraenidae by M. Jäch; Coleoptera Elateridae by G. Platia; Coleoptera Scarabaeidae by D. Keith; Coleoptera Aphodiidae by P. Bordat; Heteroptera by P. Magnien and A. Matocq; the insect material collected is preserved in their respective collections.

Table 1 summarizes the description of the five stations from which insects were collected. A more detailed description of each locality is given here: $\mathrm{K} 1$. This site is located in the northwestern corner of the Kalut formation in the floor of a NWN-SES directed valley bordered by $\sim 40 \mathrm{~m}$ high crests (Fig. 3 ). The valley floor is covered by coarse aeolian sands. K1 is located at only $1400 \mathrm{~m}$ to the Shahdad to Nehbandan road and the nearest habitations are located at about $25 \mathrm{~km}$ to the south. A halogen light was also installed in the camp site to attract insects at night.

R1. This station was located at the northwestern limit of Rig-e Yalan, inside the sand dunes (Fig. 4).

R2. Situated at the transitional zone between Rig-e Yalan erg and Central Hammada, the R2 collection site was a relatively vast hamada surface bordered by low to medium-sized ( $<50 \mathrm{~m} \mathrm{high)}$ sand dunes.

R3. This station (Fig. 6) is probably the most interesting collection site because it represents one of the supposedly hottest spots on Earth according to Mildrexler et al. (2006, 2011). Air temperatures at our arrival time (21:30 p.m. on 20/04/2014) were around $36^{\circ} \mathrm{C}$. They increased to about $50^{\circ}$ at 10:30 a.m in 21/04/2014. A data logger was installed in this site to record temperature and relative humidity over a year. The results are reported in Pourkhorsandi et al. (2019).

CH1. In the southwestern corner of the Central Hammada, the topographic difference between the surface of hamada and a vast depression covered with extensive mud flats and playas ("Hamoun-e Shūrgaz") has caused the development of relatively deep gullies draining into the depression. A permanent spring with low discharge has emerged in one of these gullies harboring a remarkable small oasislike ecosystem dominated by a healthy population of Tamarix sp. grown along the stream (Fig. 5). A water sample from the spring in $\mathrm{CH} 1$ was taken for measuring its chemical characteristics. Measurement of this sample in INIOAS analytical chemistry lab, gave a pH of 7.683, an EC of $53.1 \mathrm{mS} / \mathrm{cm}$, and a salinity of $35.2 \mathrm{ppt}$ at $28.7^{\circ} \mathrm{C}$. 


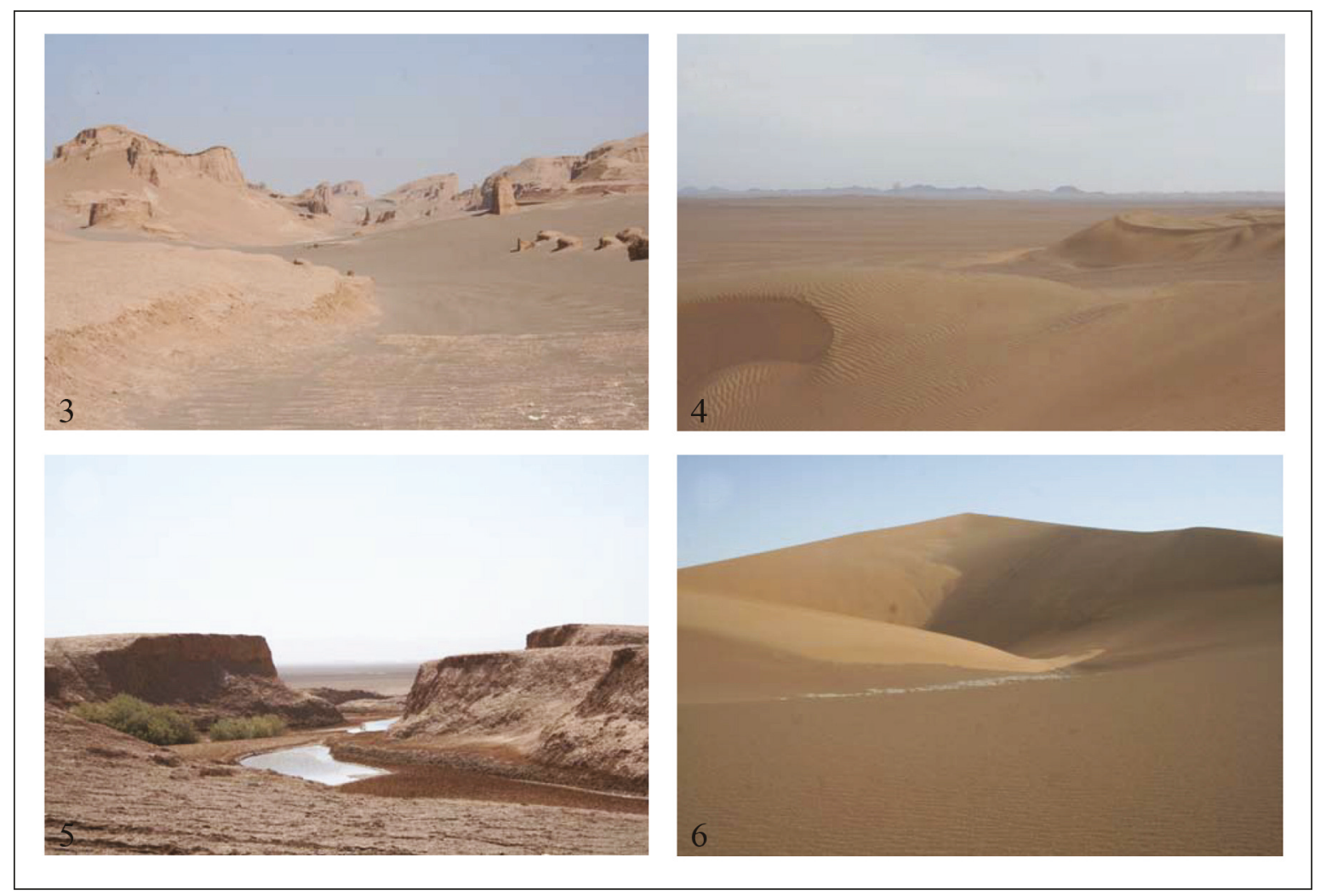

Figure 3. K1 site in northwestern border of Kalut. Figure 4. R1 site at the limit of the Rig-e Yalan and Central Hammada. Figure 5. CH1 site, Cheshmeh Shūrgaz in the transition between Kalut and the playas located in the south of Central Hammada. Figure 6. R3 site located in the supposedly hottest zone on Earth.

\section{RESULTS}

Ordo BLATTODEA Wattenwyl, 1882

Familia CORYDIIDAE Saussure, 1864

\section{Leiopteroblatta monodi Chopard, 1969}

One sand swimming cockroach specimen was collected in station R1 in the evening an hour after the sunset. This specimen corresponds to Leiopteroblatta monodi, an endemic species from the Lut desert, collected by Monod then described by Chopard (1969) and reported by Pierre (1970). As in most desert dweller cockroaches the body of $L$. monodi is covered with dense erected hairs creating a microclimate and protecting the animal from heat and dessication (Bell et al., 2007).

Ordo ORTHOPTERA Latreille, 1793

Familia ACRIDIDAE MacLeay, 1819

\section{Sphingonotus sp.}

Huge quantities of this grasshopper were observed in stations $\mathrm{R} 2, \mathrm{R} 3$, and $\mathrm{CH} 1$. In station $\mathrm{CH} 1$ we estimate the number of individuals of the grasshoppers as $10 / \mathrm{m}^{2}$.

During the 1969 field trip, Sphingonotus (Sphingonotus) theodori iranicus (Mistshenko, 1936) was the only Sphingonotus species collected by the Franco-Iranian expedition in Lut desert, and it is possible that our grasshopper corresponds to the same species.

Ordo COLEOPTERA Linnaeus, 1758

Familia CARABIDAE Latreille, 1802

\section{Megacephala (Grammognatha) euphratica Dejean, 1822}

In station $\mathrm{CH} 1$ one specimen was collected at light near the halogen lamp. This is a widespread 
species, distributed from southern Spain and North Africa to Iran and Oman, and the only member of the genus in the Palaearctic region (Puchkov \& Matalin, 2003). This Tiger-beetle is a nocturnal predatory species, frequently attracted by light, and lives in flat regions of salt-encrusted desert near to permanent water (Gillett, 1995).

\section{Calosoma (Caminara) olivieri Dejean, 1831}

In station R3 three specimens were collected at night near the halogen light. This is also a widespread predatory species, occurring from the Atlantic archipelagos (Azores, Canary, Cabo Verde) to India through North Africa. As noted by Jeannel (1940), it can lives in humid climates in the West of its distribution (Atlantic Morocco, Atlantic archipelagos) but is restricted to semi-desertic and desertic climates to the East.

Syntomus fuscomaculatus (Motschulsky, 1844)

One specimen was collected in station R3. This is another ground beetle with a very wide distribution area, found in most of the southern countries of the West Palaearctic, reaching the Oriental region (Kabak, 2003). The life habits of this species and that of other Syntomus is poorly known but they are usually found in open environments and dry habitats.

\section{Familia HYDRAENIDAE Mulsant, 1844}

\section{Ochthebius spp.}

In station $\mathrm{CH} 1,4$ specimens were collected from inside the stream. Three of the specimens seem to belong to Ochthebius andraei Breit 1920. Jäch (1992) synonymized andraei and longitarsis by Ferro 1982, which was described from SE Iran. However, there are slight differences between the type material of andraei (from Iraq) and the specimens recently collected from Lut. So maybe $O$. longitarsis could be in fact the true species, but at the moment the problem cannot be solved because it is necessary to collect and study more materials from different localities and populations. Another specimen from station $\mathrm{CH} 1$ is an immature female, which belongs to another species, but cannot be identified in the absence of males.
Familia ELATERIDAE Leach, 1815

Aeoloides grisescens (Germar, 1844)

One specimen was collected at light in station $\mathrm{K} 1$. This click-beetle of the tribe Oophorini is a species widely distributed in Europe, North Africa and Asia, in the desertic and subdesertic areas of the Palaearctic and Afrotropical regions (Cate, 2007; Platia, 2007, 2011). In Saudi Arabia, Aeoloides grisescens was collected under canopies of Acacia ehrenbergiana, Lycium shawii, Rhazya stricta and Ziziphus nummularia (Abdel-Dayem et al., 2017).

Familia COCCINELLIDAE Latreille, 1807

\section{Coccinella septempunctata Linnaeus, 1758}

One specimen was collected in station R2. This ladybird has an extremely large distribution and occupies the whole Palaearctic region, extending into the Afrotropical, Nearctic and Oriental regions (Kováŕ, 2007). In Iran it is reported from almost every province but there is no data from Lut desert according to Borumand (2000).

Familia SCARABAEIDAE Latreille, 1802

Clipadoretus cf. persicus Ohaus, 1941 (Fig. 7)

Two specimens were collected at light at station R3. Machatschke (1965) described dentatus from Nermashir. Later, Petrovitz (1967) described quadridentatus from Pakistan, Quetta, which differs at least by male genitalia, 10 - jointed antennae and the presence of a fronto-clypeal suture and was temptively placed in this genus. In fact, an acute identification is postponed to a modern revision.

Familia APHODIIDAE Leach, 1815

\section{Mendidius beluchistanicus (Petrovitz, 1962)}

One specimen was collected at light at station R3. This is a deserticolous species described from Iran (Beloutchistan). It seems that no other observations were made in Iran or elsewhere before its discovery in the eastern provinces of Saudi Arabia (Pittino, 1984). This species is also reported 


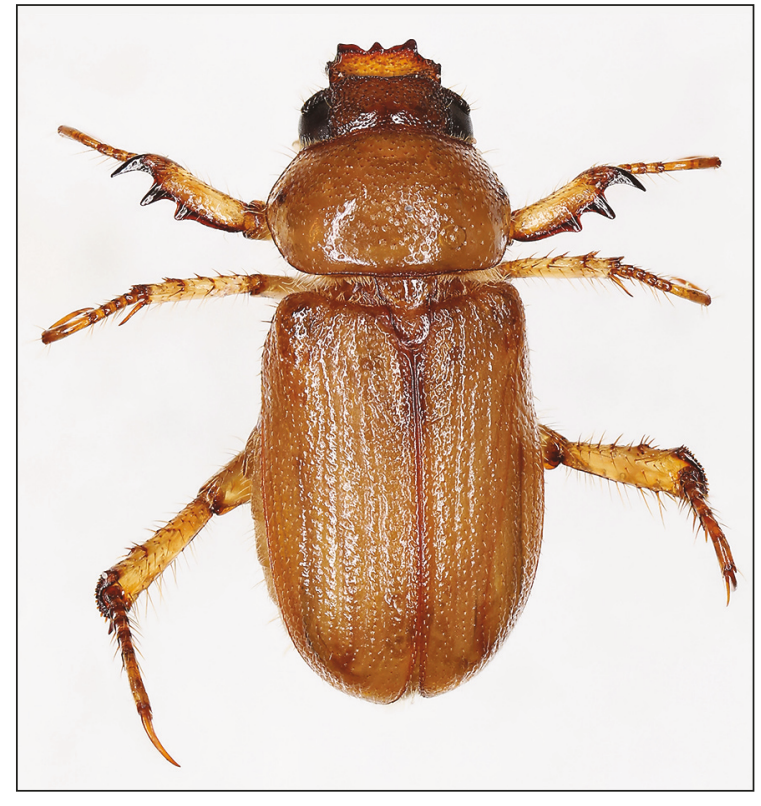

Figure 7. Clipadoretus cf. persicus Ohaus, 1941, from site R3.

from Iraq by Dellacasa \& Dellacasa (2006). Its distribution area is possibly much wider because it can be confused with a very similar species, Mendidius laevicollis (Harold, 1866)

Ordo HETEROPTERA Latreille, 1810 Familia PENTATOMIDAE Leach, 1815

\section{Brachynema germarii (Kolenati, 1846)}

One specimen was found at station R3. It is attracted by light and has already been reported from Iran (Ribes \& Pagola-Carte, 2013). In France it is a very rare species occurring only in the South, more abundant in North Africa, Egypt, Israël, Jordan, Syria, and reaches Mongolia and China to the East. This halophytic species is often found in xeric localities, on various plants growing on salty soils: Zygophyllum, Anabasis, Alhagi, Artemisia, Suadea, Beta.

Chroantha ornatula (Herrich-Schaeffer, 1842)

One specimen was found at station R3. Widespread in North Africa, Arabian Peninsula and already reported from Iran (Ribes \& Pagola-Carte, 2013). This species lives mainly on Suaeda but also on Salsola and Zygophyllum.
Familia LYGAEIDAE Schilling, 1829

Cosmopleurus fulvipes (Dallas, 1852)

One specimen was found at station R3. This species is widespread in the desertic regions of North Africa, and in the Saharo-Sindian deserts, eastwards to Pakistan. It is already reported from Iran (Péricart, 1998a). Cosmopleurus fulvipes is a xerophilous and deserticolous species. Its biology is poorly known but this Lygaeidae is probably polyphagous, with a predilection for Asclepiadiaceae such as Pergularia tomentosa.

Emblethis gracilicornis Puton, 1883

One specimen was found at station R3. As with the previous species, Emblethis gracilicornis is an Eremian element that occupies the North African and Middle Eastern deserts in the East, present in Iran (Péricart, 1998b) and reaching tropical Africa to the south. This is a polyphagous, granivorous and terricolous species.

Familia CYDNIDAE Billberg, 1820

Byrsinus nigroscutellatus (Montandon, 1900). One specimen was found at station R3. This species is reported from Algeria, Chad, Egypt, Lybia, Mauretania (Lis, 2003), and was also recently reported from Iran (Ghahari et al., 2009). Many cydnids are burrowing Heteroptera, living on soft soils, and are certainly phytophagous and radicicolous. The biology of Byrsinus nigroscutellatus seems not known.

\section{DISCUSSION: BIOGEOGRAPHICAL AND ECOLOGICAL IMPLICATIONS}

\section{An unexpectedly diverse arthropod fauna}

The most outstanding finding of this study is that there is very few common taxa between the recently collected assemblage and the assemblage collected during the Franco-Iranian mission in the late 1960's by Théodore Monod (Pierre, 1974). The following species were collected during both expeditions: Leiopteroblatta monodi, the endemic sand dweller cockroach, was collected by Monod at 
Rig-é-Lut (Rig-e Yalan); Sphingonotus sp. could correspond to Sphingonotus (Sphingonotus) theodori iranicus (Mistshenko, 1936), the sole Sphingonotus species reported from Lut by Pierre (1970); Calosoma (Caminara) olivieri was reported from many localities by Pierre (1970); Aeoloides grisescens collected in 2014 may corresponds to Aeoloides sp. reported by Pierre (1970) from Baloutchab and Shahdad river; concerning the Heteroptera Cosmopleurus fulvipes was already reported by Pierre (1970) from "Dunes au N.E. de Baloutchab". The total absence of Tenebrionidae in our material from 2014 is really unexpected since this family is the dominant beetle group in desertic regions (Dajoz, 2002).

Pierre (1970) reports about 60 taxa from the Lut Desert, later Pierre (1974) provides a more complete list concerning the groups Tenebrionidae and Scarabaeoidea only, including 26 taxa in total. The latter collection studied and published by Franklin Pierre dates to March 1970 (Pierre, 1974). Although the insect collection presented in this study was not performed in a systematic way and postdated, by about one month, the Monod's collection date, it yielded 15 taxa belonging to 4 insect orders. This taxonomic difference can be explained in several different ways. It can be due to the one-month difference in collection dates and a reflection of the different timing of the life cycles of taxa belonging to the two assemblages. However, it can also be due to different weather conditions in 1970 and 2014 winter-spring transition. The other possibility is that the taxonomic diversity of insect fauna of Lut is much more significant than expected from a subtropical hyperdesertic area. Pierre (1970) considers that the ca. 60 taxa collected during the Franco-Iranian mission of 1969 corresponds to the $2 / 3$ of the total insect fauna of the Lut region. Our results suggest that these figures may be clearly underestimated. All the above facts highlight the necessity for well-organized entomological expeditions to unravel the cryptic insect biodiversity of Lut Desert.

\section{"Aphytic" but not "abiotic"}

By far the richest arthropod assemblage was encountered at station R3, mainly around the halogen lights: in total 9 species were observed, including 4 species of Coleoptera and 5 species of Het- eroptera. This is especially interesting because this region is thought to represent the hottest spots on Earth, and is totally devoid of phanerogamic vegetation.

The high diversity of insect fauna of Rig-e Yalan and Central Hammada raises the question of the nature of food web in this extremely hot and dry desert. In the absence of any plant life in central Lut Desert especially in Kalut and Central Hammada, it is not clear what the source of primary production is. Grasshoppers constitute the most abundant herbivorous insects that consume foliage in most semi-arid and arid environments of the world and commonly prefer feeding on annual rather than perennial shrubs. However, in severe climatic conditions they may shift their feeding strategy to perennials with higher quantities of deterrents and toxins in order to keep their water balance (Otte \& Joern, 1977). We did not observe any source of primary production in the central and eastern Lut Desert. However, grasshoppers (Sphingonotus sp.) were observed feeding on dead bodies of migrating gulls, probably Larus cachinnans which is widespread in the Middle East (Porter \& Aspinall, 2010) (Fig. $8)$. Ants form the dominant surface-active arthropod faunas of the arid and semi-arid regions. Their colonies have been observed even in areas with sparse or practically no vegetation (Whitford \& Wade, 2002). However, no species of ant was observed during our expeditions to Lut. Grounddwelling beetles and particularly the detrivorous Tenebrionidae are the next most abundant groups of arthropods in these environments. According to Crawford (1988) their abundance in sand dunes has been attributed to the specific characteristics of sand dunes. The high porosity of sands permits water infiltration and accumulation in a shallow depth below surface and the low heat conductivity causes rapid temperature gradients creating survivable habitats for these insects. Abundance of these detrivorous insects can also be explained partly by trapping of wind-blown organic detritus from other areas. It is possible that the wind-blown detritus from peripheric vegetation-bearing mountain and desert steppes surrounding the Lut Desert provide the required primary biomass for the survival of the Lut insects and vertebrate fauna. Part of these organic detritus can also come from the very sparse vegetation found in the interior parts 


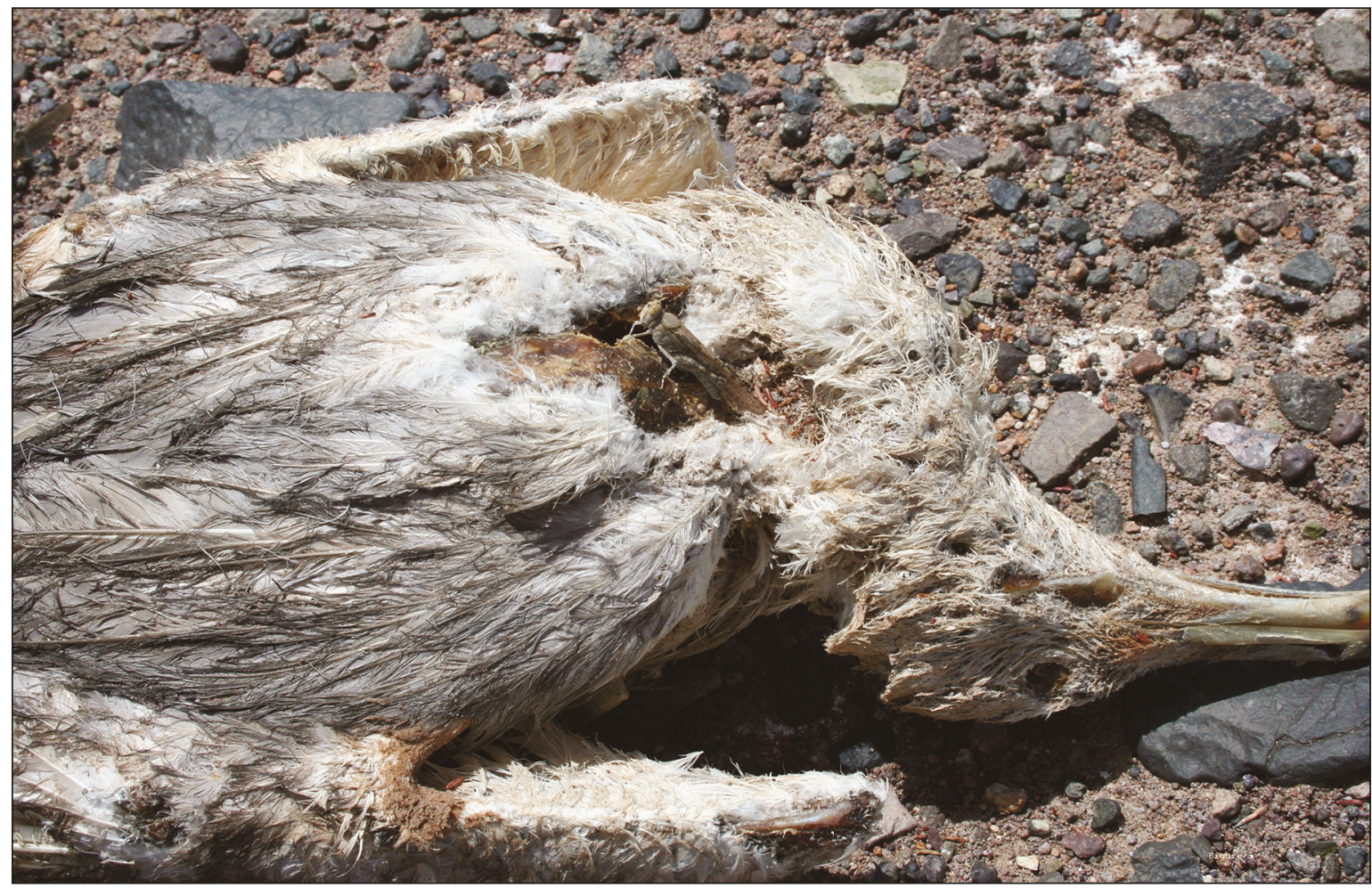

Figure 8. Sphingonotus sp. feeding on the dead body of a migrating bird, Larus cf. cachinnans.

of Rig-e Yalan.

\section{ACKNOWLEDGEMENTS}

Authors wish to thank Amirhushang Moghadam, Bahman Izadi, Arman Shakeri and Houman Shakeri for their guidance and professional support. Without their assistance and dedication which went above and beyond the call of duty, this scientific expedition would not be possible. We are also thankful to the INIOAS technical staff Naser Qassemi-Ebtehaj and Assadollah Taheri for their assistance during field works. The authorities of Kerman Province, in particular Mr. Yazdan-Panah are sincerely thanked for facilitating and supporting our field excursions. This study was supported by Iranian National Institute for Oceanography and Atmospheric Sciences (INIOAS) and the Franco-Iranian PHC Gundishapour program under Grant number 40903 funded by Iranian Ministry of Science, Research and Technology and French Ministry of Foreign Affairs. Authors also wish to thank Prof. Hossein Akhani (University of Tehran) and Prof. Reza Mansouri (Saeedi Institute of Advanced Studies) for their support during an earlier field expedition in 2014. These two expeditions were theprecursors to later intensive ecological expeditions organized by Prof. H. Akhani in 2015 (see Stone, 2016).

\section{REFERENCES}

Abdel-Dayem M.S., Fad H.H., El-Torkey A.M., Elgharbawy A.A., Aldryhim Y.N., Kondratieff B.C., Al Ansi A.N. \& Aldhafer H.M., 2017. The beetle fauna (Insecta,Coleoptera) of the Rawdhat Khorim National Park, Central Saudi Arabia. ZooKeys, 653: 1-78. https://doi.org/10.3897/zookeys.653.10252

Azarderakhsh M., Prakash S., Zhao Y. \& Aghakouchak A., 2020. Satellite-based analysis of extreme land surface temperatures and diurnal variability across the hottest place on Earth. IEEE Geoscience and Remote Sensing Letters, https:// doi.org /10.1109/ LGRS.2019. 2962055.

Bell W.J., Roth L.M. \& Nalepa C.A., 2007. Cockroaches: ecology, behavior, and natural history. Baltimore, Johns Hopkins University Press, 230 pp. https://doi. org/10.1086/590617

Borumand H., 2000. The List of Coleoptera in the Insect Collection of Plant Pests \& Diseases Research Insti- 
tute of Iran, Coleoptera Coccinellidae. Insect Taxonomy Research Department Publ. N ${ }^{\circ}$ 5, Plant Pests \& Diseases Research Institute, Ministry of Agriculture, Agricultural Research, Education \& Extension Organization, Tehran, 44 pp.

Cate P.C., 2007. Elateridae. In: Löbl I. \& Smetana A., 2007. Catalogue of Palaearctic Coleoptera vol. 4. Apollo Books, Stenstrup, 89-209.

Chopard L., 1969. Description d'une intéressante blatte du désert iranien [Dictyopt. Polyphagidae]. Bulletin de la société entomologique de France, 74: 228-230.

Crawford C.S., 1988. Surface-active arthropods in a desert landscape: influences of microclimate, vegetation, and soil texture on assemblage structure. Pedologia, 32: 373-385.

Dajoz R., 2002. Les Coléoptères Carabidés et Ténébrionidés. Lavoisier/TEC \& DOC, Paris, 522 pp.

Dellacasa M. \& Dellacasa G., 2006. Tribe Aphodiini. In: Löbl I. \& Smetana A. 2006. Catalogue of Palaearctic Coleoptera vol. 3. Apollo Books, Stenstrup, 105-142.

Djamali M., Akhani H., Khoshravesh R., Andrieu-Ponel V., Ponel P. \& Brewer S., 2011. Application of the Global Bioclimatic Classification to Iran: implications for understanding the modern vegetation and biogeography. Ecologia Mediterranea, 37: 91-114. https://doi.org/10.3406/ecmed.2011.1350

Djamali M., Brewer S., Breckle S. \& Jackson S.T., 2012. Climatic determinism in phytogeographic regionalization: a test from the Irano-Turanian region, SW and CentralAsia. Flora, 207: 237-249. https: //doi.org/10.1016/j.flora.2012.01.009

Dresch M.J., 1968. Reconnaissance dans le Lut (Iran). Bulletin de l'Association de Géographes Français, 362-363, 143-153.

Gabriel A., 1938. The southern Lut and Iranian Baluchistan. The Geographical Journal, 92: 193-208.

Ghahari H., Chérot F., Linnavuori R.E. \& Ostovan H., 2009. Annotated catalogue of Iranian burrower bugs (Heteroptera, Pentatomopidea, Cydnidae). ZooKeys, 26: 1-31. https://doi.org/10.3897/zookeys.26.214

Ghodsi M., 2017. Morphometric characteristics of Yardangs in the Lut Desert, Iran. Desert, 22: 21-29. https://doi.org/10.22059/jdesert.2017.62251

Gillett M., 1995. An annotated and illustrated checklist of Tiger Beetles recorded from the Al Ain/Buraimi region of Eastern Arabia (Coleoptera: Cicindelidae). Tribulus, 5: 13-16.

Jäch M.A., 1992. Revision of the Palaearctic species of the genus Ochthebius Leach, 1815. IX. The andraei and notabilis species groups. Nachrichtenblatt der Bayerischen Entomologen, 41: 7-21.

Jeannel R., 1940. Les Calosomes. Mémoires du Muséum national d'Histoire naturelle, N.S., 13: 1-240.

Kabak I., 2003. Lebiini. In: Löbl I. \& Smetana A., 2003.
Catalogue of Palaearctic Coleoptera vol. 1. Apollo Books, Stenstrup, 408-439.

Kovář I., 2007. Coccinellidae. In: Löbl I. \& Smetana A., 2007. Catalogue of Palaearctic Coleoptera vol. 4. Apollo Books, Stenstrup, 568-631.

Léonard J., 1981-1989. Contribution à l'étude de la flore et de la végétation des déserts d'Iran. Etude des aires de distribution les phytochories, les chorotypes. Fascicules, 1-9. Meise, Jardin botanique national de Belgique.

Léonard J., 1991/1992. Contribution à l'étude de la flore et de la végétation des déserts d'Iran. Étude delavégétation: analyse phytosociologique et phytochorologique des groupements végétaux, Fascicule 10. Meise, Jardin botanique national de Belgique.

Léonard J., 1993. Comparisons between the phytochorological spectra of three Iranian deserts and those of various surrounding regions. Bulletin du Jardin Botanique Naturel de Belgique, 62: 389-396.

Lis J., 2003. A redescription of Byrsinus nigroscutellatus (Montandon) comb. n. (Hemiptera: Heteroptera: Cydnidae), with remarks on the synonymy of Byrsinocoris Montandon,1900 and Byrsinus Fieber, 1860. Polskie Pismo Entomologiczne, 72: 39-44.

Machatschke J.W., 1965. Ein neuer Clipadoretus aus Persien und kritische Bemerkungen zur Gattung Clipadoretus Ohaus (Coleoptera: Lamellicornia, Melolonthidae, Rutelinae Orthochilidae, Adoretini). Arbeiten aus dem Museum G. Frey, 16: 131-138.

Mildrexler D.J., Zhao M. \& Running W., 2006. Where are the hottest spots on Earth? EOS, 87: 467. https://doi.org/10.1029/2006EO430002

Mildrexler D.J., Zhao M. \& Running W., 2011. Satellite finds highest land skin temperatures on Earth. Bulletin of American Meteorological Society, 92: 855-860. https://doi.org/10.1175/2011BAMS3067.1

Mobayen S., 1976. Structure géobotanique du Loute. Acta Ecologica Iranica, 1: 73-86.

Monod T., 1973. Les déserts. Horizons de France, Paris, $248 \mathrm{pp}$.

Otte D. \& Joern A., 1977. On feeding patterns in desert grasshoppers and the evolution of specialized diets. Proceedings of the Academy of Natural Sciences of Philadelphia, 128: 89-126. https://www.jstor.org/stable/4064720

Péricart J., 1998a. Hémiptères Lygaeidae euro-méditerranéens vol.1, Généralités, systématique, Faune de France 84. A. Fédération Française des Sociétés de Sciences Naturelles, Paris, 468 pp.

Péricart J., 1998b. Hémiptères Lygaeidae euro-méditerranéens vol. 3, Systématique: troisième partie Rhyparochrominae (2), Faune de France 84 C. Fédération Française des Sociétés de Sciences Naturelles, Paris, $487 \mathrm{pp}$.

Petrovitz R., 1967. Österreichische entomologische 
Expeditionen nach Persien und Afghanistan. Beiträge zur Coleopterologie Teil XI. Lamellicornia. Annalen des Naturhistorischen Museums in Wien, 70: 479-490. https://www.jstor.org/stable/ 41781575

Pierre F., 1969. Observations écologiques et biogéographiques sur le désert du Lut (Sud de l'Iran). La Terre et la Vie, 116: 125-134. http://hdl.handle.net/ 2042/58942

Pierre F., 1970. Observations écologiques et biogéographiques sur le désert du Lut, Sud de l'Iran (Deuxième note). La Terre et la Vie, 117: 311-330. http:// hdl.handle.net/2042/58744

Pierre F., 1974. Contribution à la faune de l'Iran: insectes coléoptères du désert du Lut. Annales de la Société Entomologique de France, 10: 229-235.

Pittino R., 1984. Insects of Saudi Arabia. Coleoptera Scarabaeoidea: a revision of the family Aphodiidae. Fauna of Saudi Arabia, 6: 267-360.

Porter R. \& Aspinall S., 2010. Birds of the Middle East. Helm Field Guides, Christopher Helm, London, 384 pp.

Platia G., 2007. Order Coleoptera, family Elateridae. Arthropod fauna of the UAE, 1: 194-210.

Platia G., 2011. New species and new records of clickbeetles from the Palaearctic region (Coleoptera Ela- teridae). Boletín de la Sociedad Entomológica Aragonesa, 48: 47-60.

Pourkhorsandi H., Gattacecca J., Rochette P., D’Orazio M., Kamali H., Avillez R. de., Letichevsky S., Djamali M., Mirnejad H., Debaille V. \& Jull A.J.T., 2019. Meteorites from the Lut Desert (Iran). Meteoritics and Planetary Science, 54: 1737-1763. https://doi.org/10.1111/maps.13311

Puchkov A.V. \& Matalin A.V., 2003. Cicindelinae. In: Löbl I. \& Smetana A., 2003. Catalogue of Palaearctic Coleoptera vol. 1. Apollo Books, Stenstrup, 99-118.

Ribes J. \& Pagola-Carte S., 2013. Hémiptères Pentatomoidea Euro-Méditerranéens vol. 2. Fédération Française des Sociétés de Sciences Naturelles, Paris, $423 \mathrm{pp}$.

Stöcklin J., 1968. Structural history and tectonics of Iran: a review. The American Association of Petroleum Geologists Bulletin, 52: 1229-1258. https://doi.org 10.1306/5D25C4A5-16C1-11D7-8645000102C18 $65 \mathrm{D}$

Stone R., 2016. The incredible ecosystem of Eart's hottest spot. Science https://doi.org/10.1126/science. aal0513.

Stratil-Sauer G., 1956. Forschungen in der WustLut. Wissenschaftliche Zeitschrift der Martin LutherUniversität Halle, 3: 569-574.Whitford W. \& Wade 